INSIGHTS INTO REGIONAL DEVELOPMENT

ISSN 2669-0195 (online) http://jssidoi.org/IRD/

2021 Volume 3 Number 2 (June)

http://doi.org/10.9770/IRD.2021.3.2(6)

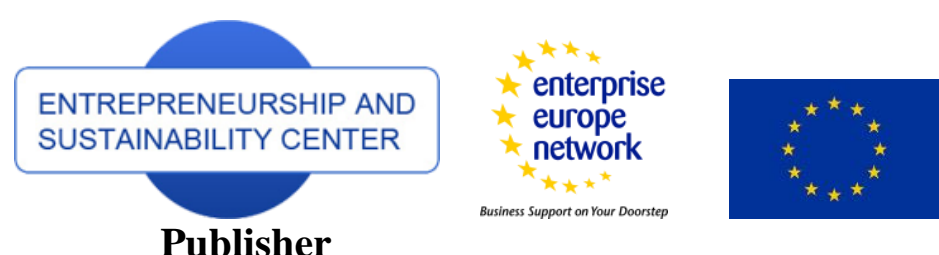

http://jssidoi.org/esc/home

\title{
SMALL AND MEDIUM ENTERPRISES IN REGIONS - EMPIRICAL AND QUANTITATIVE APPROACH*
}

\author{
Ladislav Mura ${ }^{\text {, }}$ Zuzana Hajduová ${ }^{2}$ \\ ${ }^{1}$ Pan-European University, Faculty of Economics and Business, Tematinska 10, 85105 Bratislava, Slovakia \\ ${ }^{2}$ University of Economics in Bratislava, Faculty of Business Management, Dolnozemská cesta 1, 85235 \\ Bratislava, Slovakia
}

E-mails: ${ }^{1}$ ladislav.mura@gmail.com; ${ }^{2}$ zuzana.hajduova@euba.sk

Received 20 November 2020; accepted 12 April 2021; published 30 June 2021

\begin{abstract}
The problem of identifying and quantifying the efficiency of accommodation units is currently a discussed issue. Recognition and identification of the most important aspects that increase the financial efficiency of a rapidly changing business environment, especially in a difficult period of economic and tourism bounce back is a key issue. Only the companies that adequately address the issue of their measurement and evaluation and are able to choose the right approach in this regard will win the competition. Our work focuses on the identification of key factors influencing the management of business entities. We carried out a detailed analysis of accommodation units in selected accommodation facilities at the regional level. We wanted to point out the differences within the individual regions of Slovakia. By applying the DEA method, we used individual models focused on inputs and outputs in order to determine the inefficient units in our research, and revealed its shortcomings and pointed out the way to improve the economic results of these research subjects.
\end{abstract}

Keywords: small and medium enterprises; regions; DEA; models; correlation

Reference to this paper should be made as follows: Mura, L., Hajduová, Z. 2021. Small and medium enterprises in regions - empirical and quantitative approach. Insights into Regional Development, 3(2), 252-266. http://doi.org/10.9770/IRD.2021.3.2(6)

JEL Classifications: C14, C44, L21

\footnotetext{
* Scientific Paper was elaborated and financed within the framework of the project VEGA 1/0813/19 Managing the development of innovative and start-up forms of businesses in international environment and verification of INMARK concept and GAAA 5-5/2020 Development of family business in Slovak regions. This research was funded by VEGA 1/0240/20 Financial aspects of business sustainability - business succession in small and medium enterprises, too.
} 
INSIGHTS INTO REGIONAL DEVELOPMENT

ISSN 2669-0195 (online) http://jssidoi.org/jesi/

2021 Volume 3 Number 2 (June)

http://doi.org/10.9770/IRD.2021.3.2(6)

\section{Introduction}

The focus of this research is to identify the relationship between the key economic factors and the efficiency of businesses (Belas et al., 2020; Baša et al., 2019), which we examine through interrelated financial indicators. The concept of performance is compared to the productive capacity of the company in terms of achieving performance in individual research areas (Duygulu et al., 2016). In today's global environment, it is the best to define business performance as market success (Teles, Schachtebeck, 2019; Wach, 2020), the ability to succeed in competition, and find opportunities for further growth in a changing unstable environment (Thames et al. 2016; Cepel et al., 2018; Stacho et al., 2021). Tumpach (2008) considers efficiency to be one of the main criteria for evaluating the company's results and defines it as a measure of achieving the set goals and creating conditions for their fulfillment in the future (Herman et al., 2018). Business performance has been examined from different perspectives, but flexible reaction to the changing environment is important (Aisyah et al., 2017; Aisyah et al., 2017). According to Sahid et al. (2018), efficiency is achieved if the company is able to increase the resulting volume of outputs while maintaining an identical amount of inputs. However, efficiency can also be increased while maintaining the required final output and limiting the resources expended to achieve it. The most important factor is the efficiency criterion, which expresses the ratio between the outputs of economic activity and the given inputs. A large number of modern efficiency measurement models have emerged due to the development of statistical methods, information technology, as well as growing interest from banks, rating agencies and businesses (Kozubikova, Kotaskova, 2019; Obeidat et al. 2016; Curado et al. 2018; Morrison.2011). The overall efficiency of a company can be assessed in the context of the company's strategy. Waal (2013), Borocki et al. (2019) define the strategic performance as the company's ability to achieve the determined strategic goals. Dad. et al. (2012) point out, however, the company is evaluated by different market players from different perspectives (Kokocinska, Puziak, 2018; Krizanova et al., 2018), the concept of efficiency acquires a relative and at the same time very complex character. One recent study by Shih (2018) states that the efficiency of a business entity is most affected by its ability to innovate radically and achieve a competitive advantage through an established brand and products offered. Another new study showed that a company's performance is directly positively affected only by its strategic orientation and indirectly by its organizational structure and different production capabilities (Chatzoglou et al., 2018). A large number of studies examine for example Udriyah, 2019; Tien et al., 2018, but also setting business goals in the SME segment (Virglerova et al., 2020; Csabay, Stehlikova, 2020; Chong et al. 2019; Lazikova et al., 2018; Binh, 2010; in a family business environment (Ballini et al., 2019; Dagnino et al., 2017; Zahra, 2017; Ślusarczyk, U1 Haque, 2019). The influence of institutional factors on ensuring the innovative performance of SMEs deserves attention. SMEs have become an important area of research in the last years of our century (European Commission, 2016; Cibik, 2018; Podhorska et al., 2019). The aim of this research is to reveal the influence of orientation on the interaction of individual inputs and the effective operation of companies in the field of services (European Commission, 2017). Factors with a direct impact on the level of business affect the results in the field of finance, quality of production, increase in revenues, reduction of costs, increase in profits, influence of liquidity of companies, stock levels (Muhammand Khan, 2020; Tamulevičienè, Androniceanu, 2020).

However, the number of studies evaluating effectiveness at regional level is relatively low compared to the number of studies evaluating individual countries. We focused on and a reviewed the efficiency of accommodation facilities in the regions of the Slovak Republic. Tourism, as an important sector of the Slovak economy was significantly affected by the pandemic. It is necessary to kick start the economic recovery, also by increasing the performance of business entities in the field of accommodation services. It is necessary to realize that in the time of the ongoing recession of the world economy, tourism, as a cross-cutting sector of the national economy, is one of the ways to increase state budget revenues and improve the economic situation and employment not only in regions with potential for its development (Smerek, Vetráková, 2020; Machyniak, 2018; 
Imrovic, Kovacik, 2019). Domestic tourism is an important source of value creation - GDP (Matijová et al, 2019), foreign exchange incomes, job creation and has the potential to play a significant role in revitalizing the economically weaker regions, respectively to become an accelerator of regional development with the assumption of balancing regional disparities (Maris, 2015; Štefko et al., 2017; Melichová et al., 2017; Vekic et al., 2020). Domestic tourism represents a significant source of revenue to the state budget in Slovakia. In addition to economic, it also fulfills social, health and cultural functions (Bačík et al., 2019), helps to become aware of cultural and natural heritage, social integration, national harmony of residents and motivates the optimal use of free time.

\section{Current situation}

In 2018, 4,007 accommodation facilities were registered in the regions of Slovakia. Most of these facilities were located in the Žilina region, up to $27 \%$ of the total number and in the Prešov region $18 \%$. The overall growing trend in a positive sense was recorded by the Trnava region with a growth value of up to $39 \%$ (Fig. 1).

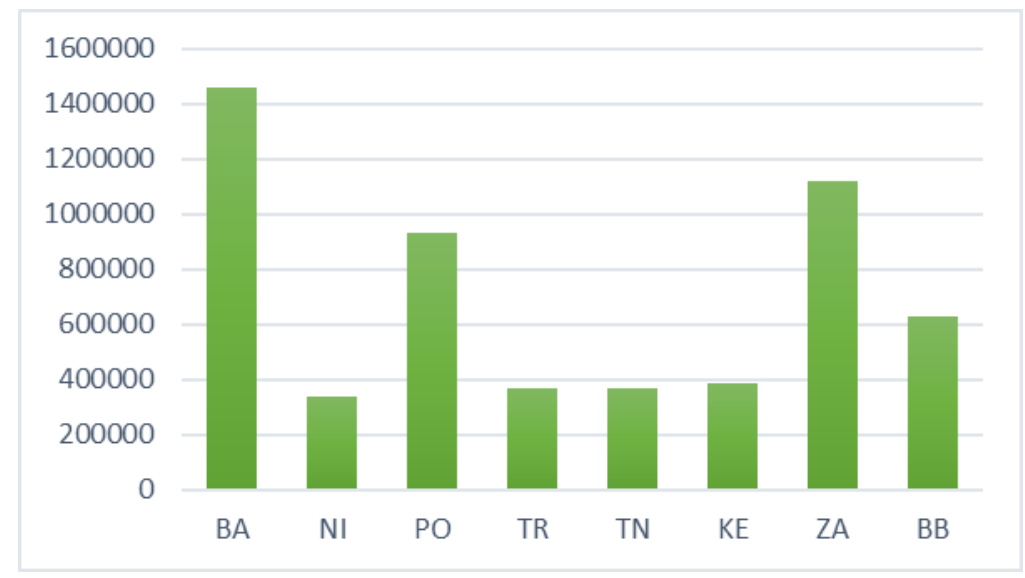

Figure 1. Visitors by regions in SR 2018

Source: own processing

Bratislava region is in leading position with the number of accommodated guests up to $1,460,000$, which represents up to $25 \%$ of the total revenue from the segment with a volume of 429,000,000 euros (Fig. 2).

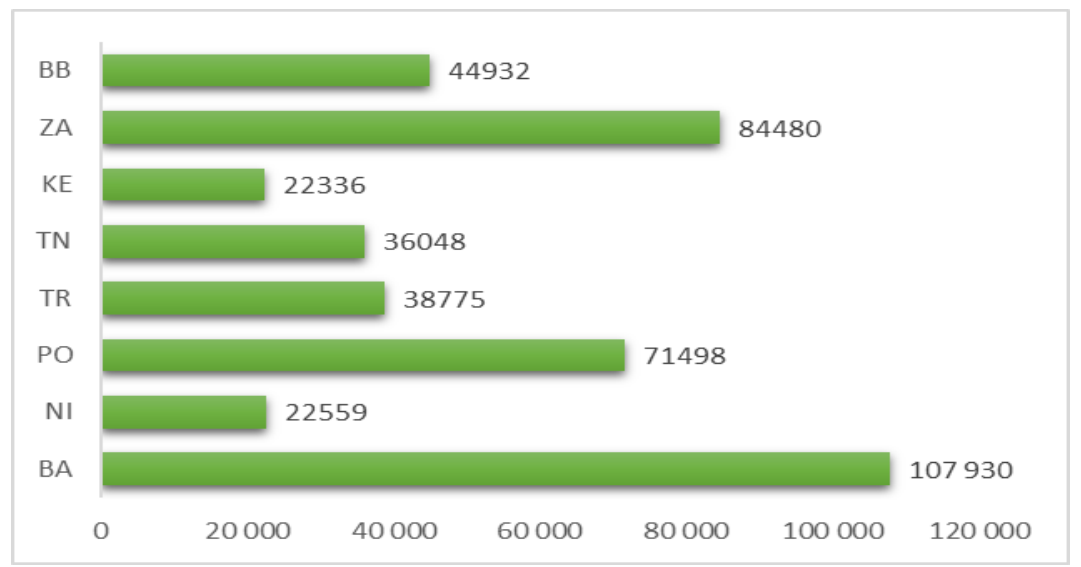

Figure 2. Revenues of accommodation facilitiesby in SR 2018 


\section{Source: own processing}

We would like to evaluate the development of efficiency of accommodation facilities in individual regions in connection with the development of tourism in Slovakia. In 2019 we recorded an increase in this segment by $22.1 \%$ compared to 2018 . This means that up to 48,042 people used the services of these facilities. While comparing the ratio of foreign and domestic visitors, we can assume an increasing trend of domestic visitors to $27.6 \%$. In the monitored period, about 158,790 foreigners visited the regions of Slovakia and used the services of accommodation units. The number of accommodation establishments in the observed period from 2018 to 2019 increased annually by an average of $11.7 \%$ (Table 1 ).

Table 1. Capacity of tourism accommodation establishments 2019

\begin{tabular}{|c|c|c|c|c|}
\hline Regions of SR & & $\begin{array}{c}\text { Number of accommodattion } \\
\text { establishments }\end{array}$ & $\begin{array}{l}\text { Occupancy rates of } \\
\text { bedrooms }(\%)\end{array}$ & $\begin{array}{c}\text { Number of } \\
\text { bedrooms(total) }\end{array}$ \\
\hline Bratislava region & BA & 385 & 45,4 & 24238 \\
\hline Trenčin region & $\mathrm{TN}$ & 323 & 39,2 & 15153 \\
\hline Nitria region & NI & 399 & 26,5 & 15341 \\
\hline Prešov region & $\mathrm{PO}$ & 853 & 32,6 & 33977 \\
\hline Košice region & $\mathrm{KE}$ & 385 & 26,4 & 14905 \\
\hline Total & SR & 4473 & 35,1 & 185395 \\
\hline
\end{tabular}

Source: own processing

These statistics prove that tourism in Slovakia has recorded a rapid increase in recent years, but a new situation has occurred the accommodation units have to deal with. In the last decade, the Slovak Republic (SR) has gained popularity as an international and domestic destination. It ranked on the 43rd position based on the number of foreign tourists arrival. The perspectives for international and domestic tourism for the country as a whole are therefore clear. According to the data of the United Nations World Tourism Organization (UNWTO), the income from tourism in Slovakia increased from 6.2 million to 9.1 million EUR. These statistics prove that tourism in Slovakia has seen a rapid increase in recent years, but the impact of COVID-19 created new circumstances that the accommodation units have to deal with.

Nowadays, tourism is one of the sectors most affected by the measures taken against the spread of COVID-19. The development of tourist accommodation statistics was therefore very specific in April 2020. The almost 
complete closure of tourism services and radical restrictions on travel at national and international level has led to a drop in number of visitors. Tourism businesses are facing existential problems and need to increase their efficiency in order to survive this difficult period. Even if they manage to survive, their financial health and stability will be marked by high to chronic indebtedness. However, many regions are already losing sources of funding today because they have lost income from accommodation tax due to the widespread closure of facilities. Accommodation tax is paid by the visitor when staying in the facility, usually up to one euro per person / overnight stay. In 2018, the revenues of communities from this tax amounted to more than 15 mil. $€$. The estimated loss of income of communities from this tax for the last months as a result of tourism slowdown was is more than 4.5 mil. $€$. The figures since the beginning of 2020 are very unfavorable (Fig. 3). While in April 2020, only 417 foreigners were accommodated in these facilities, at the same time in 2019 it was 171,000 visitors. 1.1 million visitors have been accommodated in tourism facilities since January 2020, which represents an annual decrease of $35.8 \%$. In detailed figures, 705,857 (64.8\%) were domestic visitors and 383,435 foreigners (percentage data). The number of domestic visitors decreased annually by $34.3 \%$ and the number of foreigners by $38.3 \%$. The number of overnight stays also decreased by about a third (3.1 million nights).

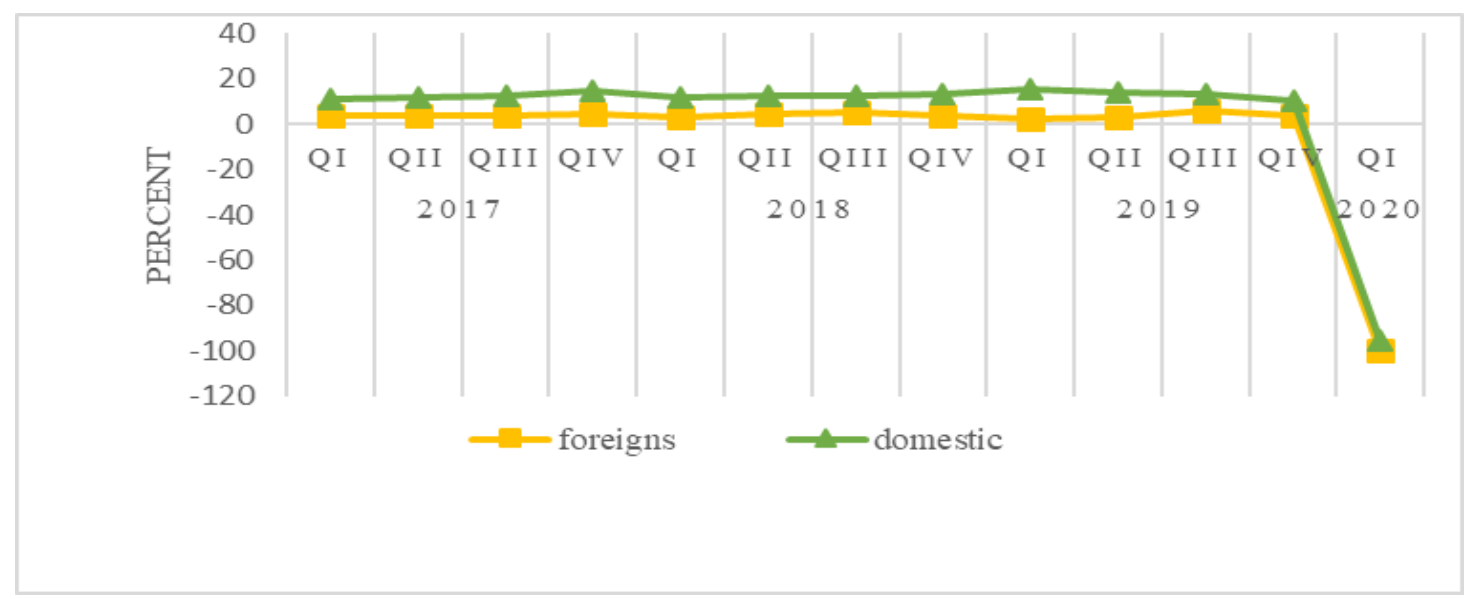

Figure 3. Development of number visitors (2017-2018)

Source: own processing

\section{Methods, methodology and research data}

Based on a review of the literature, we identified that the Data emoloyment analysis (DEA) is a widely used method for evaluating efficiency in health care but also in the environment. Its theoretical foundations were laid by (Farrell, 1957; Charnes, A,1984) and subsequently developed in many other studies. Cooper et al. (2007) made significant theoretical development. They proposed models that assume either constant returns to scale, the socalled CCR DEA models, and models that assume variable returns to scale, the so-called BCC DEA models. In this paper, we will use exclusively input-oriented DEA models, as in terms of the models used, the influence of inputs and not outputs can be assumed. Moreover, in terms of efficiency results, this is irrelevant, as output efficiency is only the inverse of input efficiency.

Relative efficiency DMUj, $\mathrm{j}=1, \ldots, \mathrm{n}$ are defined as a function of the determined factors as follows: 


$$
E_{j}(u, v)=\frac{y_{j u}^{T}}{x_{i}^{T} v}
$$

Assuming that we have m input items and s output items, we have determined individual $D M U j$ from a set of $\mathrm{n}$ units we will record input data $\left(x_{1 j}, \ldots, x_{m j}\right)$ in the matrix $\mathrm{X}$ and output data $\left(y_{1 j}, \ldots, y_{s j}\right)$ in the matrix $\mathrm{Y}$. Then it has matrix X size (m x n) and matrix Y size (s x n),(Mardani et al.,2017):

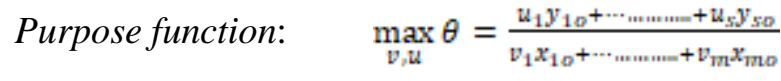

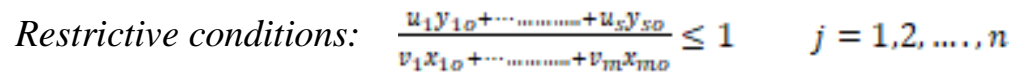

Non-negative condition $\quad V_{1}, \ldots \ldots \ldots v_{m} \geq 0 ; u_{1, \ldots \ldots \ldots} u_{g} \geq 0$

CCR DEA model - input-oriented CCR model based on standardization of the value of $x_{j}^{T} v=1$ assesses the efficiency of units. The DMUj for which it applies is considered effective $E_{j}\left(\widehat{u_{j}}, \widehat{v}, \hat{j}_{a}\right)=1$ and $\mathrm{u}>0, \mathrm{v}>0$.

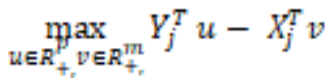

$$
\begin{aligned}
& Y_{j}^{T} u-X_{j}^{T} v \leq 0 \\
& u \geq 1_{v} v \geq 1
\end{aligned}
$$

The BCC DEA input model also focuses on a detailed analysis of inputs with both positive and negative trends. This model is calculated as the follows: ( McDonald,2009; Shi et al., 2010):

$$
\begin{gathered}
\min _{\theta \lambda l s e} \theta-e\left(1^{T} s+1^{T} e\right) \\
Y \lambda-s=Y_{j} \\
-X \lambda+\theta X_{j}-e=0 \\
1^{T} \lambda=1 \\
\lambda \geq 0, e \geq 1, s \geq 0
\end{gathered}
$$

The result of solving $\mathrm{n}$ problems, but not necessarily $\mathrm{n}$ different levels, because the level that belongs to the effective DMUj may be the closest level for any with inefficient DMUj (Ramanathan,2011; Fernandes et al.,2018). The input CCR and BCC models assume the total independence of the inputs (or outputs) so the input (or output) of any given DMU does not affect the input (or output) of other units. However, this independence does not always exist, for example in a competitive market or in the case of constant demand for production then it is appropriate to use the ZSG-DEA model.The monitored DMU reaches the effective limit just by changing the limit itself. The basic approach of this model is a proportional reduction of inputs. In particular, an inefficient DMU must lose a certain number of inputs (or receive a certain number of outputs). DMU is looking for an effective boundary, assuming that the sum of the inputs is constant. The mathematical entry is the following: 
Purpose function: $\quad \min \mathrm{h}_{\mathrm{R} 0}$

$$
h_{R 0} x_{0} \geq \sum_{k} \lambda_{k} x_{k}\left[1+\frac{x_{0}\left[1-h_{\bar{R} 0}\right)}{\sum_{k \neq 0} x_{k}}\right] ;
$$

Restrictive conditions:

$\sum_{k} \lambda_{k} y_{k} \geq y_{0}$

Non-negative condition:

$$
\lambda_{k} \geq 0 ; \vee k
$$

\section{Results}

During the assessment of the efficiency of the given segment within the regions, we chose suitable DMU units from each region. It was a sample of 40 accommodation units as a random selection from all regions of Slovakia. We selected five accommodation facilities from each region of Slovakia that were comparable to each other and had the same parameters. This step was necessary to maintain the homogeneity of the individual DMUs. The next step in the implementation was the identification and quantification of the determined factors within the use of DEA methodology. The trend in our segment is to increase outputs while maintaining the same inputs, or increasing outputs when decreasing inputs.

We have chosen the following parameters for the input parameters: employees, receivables, external sources, total assets, inventories. The output variables we determined as the follows: total sales, equity, net profit. For clarity, we named the individual DMUs by region and serial number. Using correlations, we verified the relationships between the individual parameters of the model. In our case, in the table of the correlation matrix we present the relationship between the units such as inventories, receivables for this reason (Table 2.).

Table 2. Input correlations

\begin{tabular}{|lllll|} 
& Resources & Receivables & Liabilities & Employees \\
\hline Resources & 1 & & \\
\hline Receivables & 0,15766 & 1 & & \\
\hline Liabilities & 0,10011 & 0,19871 & 1 & 1 \\
\hline Employees & 0,13131 & 0,15002 & 0,21421 & 0,25451 \\
\hline Assets & 0,24581 & 0,384982 & 0,15926 & 1 \\
\hline
\end{tabular}

Source: own processing 


\section{Model CCR-input}

As it is important to monitor and examine the development of efficiency for the subjects examined individually, we will graphically display the results for all subjects during the research period 2013-2018. Figure 4. shows the development and quantitative expression of measured values in individual subjects, given the range of data. The horizontal axis does not include all years in the form of a legend, but the individual vertical columns present the trend of efficiency development by region.

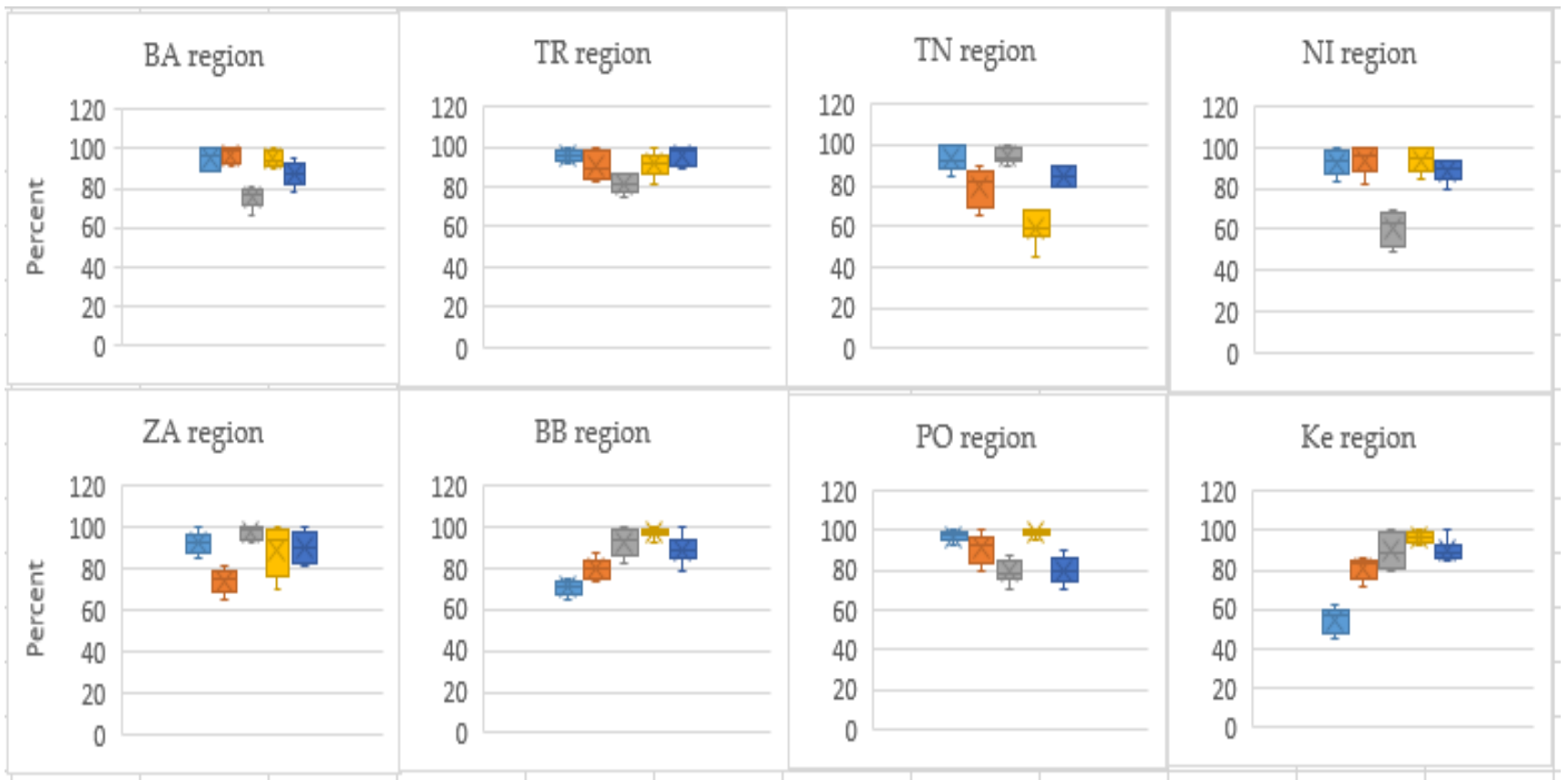

Figure 4. Result values of input oriented CCR-I model

Source: own processing

In 2018, we accurately evaluated the inputs that need to be reduced for individual entities and for DMUs that were inefficient. In the efficiency mode, there are 25 units, whose purpose function is on level 1 . These units are declared as CCR-inputs efficient. We consider other units to be inefficient. Since we need to evaluate their status, we have quantified the unit for all units formed by the weighted sum of peer units. Due to the large scope of research, we present only the resulting $\lambda$ for individual companies (Table 3 .). 
Table 3. Sum of peer units for inefficient -DMUs

\begin{tabular}{|l|c|}
\hline DMU & Suma $\lambda$ \\
\hline BA 5 & 0,164 \\
\hline NI 20 & 0,061 \\
\hline PO 35 & 0,045 \\
\hline TN 15 & 0,111 \\
\hline PO 33 & 0,035 \\
\hline TR8 & 0,245 \\
\hline TN 12 & 0,221 \\
\hline KE37 & 0,312 \\
\hline BB 27 & 0,041 \\
\hline ZA 22 & 0,054 \\
\hline BA 3 & 0,123 \\
\hline BB26 & 0,237 \\
\hline TN 14 & 0,201 \\
\hline NI 18 & 0,118 \\
\hline KE36 & 0,025 \\
\hline
\end{tabular}

Source: own processing

An example is the analysis of the BA5 unit (Table 4.). As a result of accurate analysis, we concluded that the subject BA5, which is ineffective, has a total of four peer units. The inputs of this unit are listed in the table.

Table 4. Peer unit for the selected subject

\begin{tabular}{|ccccccccccc} 
DMU & Peer & $\lambda$ & Peer & $\lambda$ & Peer & $\lambda$ & Peer & $\lambda$ & SUM $\lambda$ \\
\hline BA5 & BA2 & $\mathbf{0 , 0 3 3}$ & TN11 & 0,019 & TR9 & $\mathbf{0 , 0 2 7}$ & ZA24 & $\mathbf{0 , 0 8 5}$ & $\mathbf{0 , 1 6 4}$ \\
& & & & & & & & & \\
\hline
\end{tabular}

Source: own processing

The BA5 unit has a total of 4 peer units. For this DMU, the sum of the values of $\lambda$ is equal to 0,164 . The inputs of this unit should be $20.12 \%$ identical to the inputs of the BA2 unit, $11.59 \%$ identical to the inputs of the TN11 unit, $16.45 \%$ identical to the inputs of the TR9 unit and 51.82\% identical to the inputs of the ZA24 unit.

According to the analysis, we can precisely determine the changes in inputs for individual entities. As a conclusion of the CCR-input model analysis, we state that in all units it is necessary to rapidly reduce inputs in order to get these units to a level that we consider effective. It is essential to regulate the entry of stocks and reduce them by up to $58 \%$, then it is necessary to address the issue of human resources and overemployment. It is 
also important to eliminate overemployment in inefficient units by up to $49 \%$, and the last very important item of change is the reduction of total assets by more than $51 \%$.

\section{Model BCC-input}

This model is also focusing on input evaluation. In the variable-scale /variable yield assessment mode, 36 units reached the value of purpose function 1. It means $100 \%$, so these units lie at the limit of production possibilities and are considered BCC-I effective. Figure 5. shows the development and amount of measured values in individual entities (2013-2018).

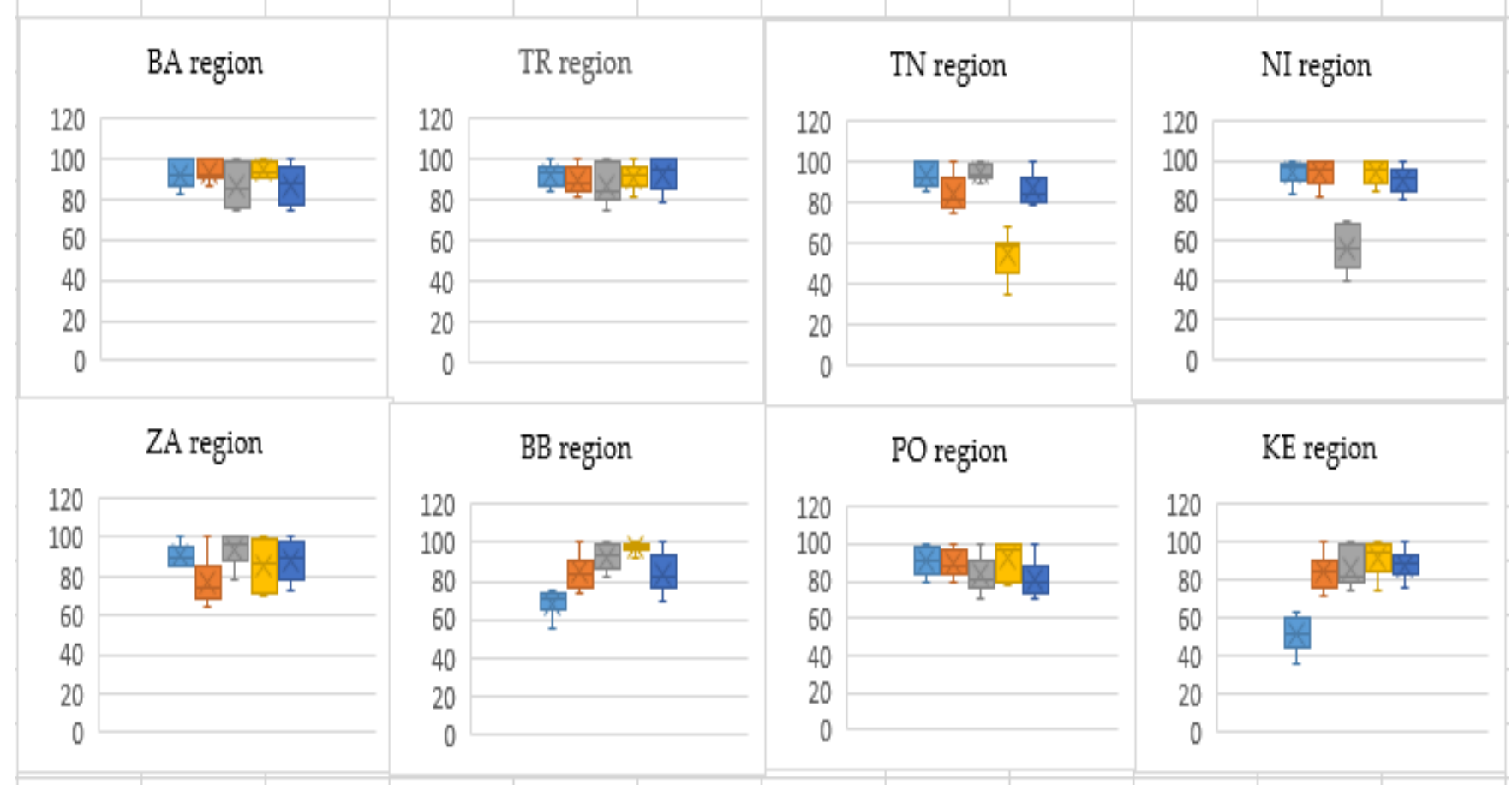

Figure 5. Result values of input oriented BCC-I model

Source: own processing

In 2018, we accurately evaluated the inputs that need to be reduced for individual entities and for DMUs that were inefficient. Thanks to the dual model, it is possible to read from the results not only the current efficiency level of individual DMUs, but also the extent to which individual inputs must be reduced, so that the unit reaches the efficiency limit. Specifically, it is about reducing the inputs of inefficient units, which are - TN14, NI18, BB26, KE36. We proceeded analogously as in the analysis of the CCR-input model, by calculating peer units for the inefficient subjects. In the table we present the changes of individual inputs of inefficient units in percentage. These inputs with the stated value must be reduced. It can be said that all inputs must be reduced in the case of inefficient units, so that the individual DMUs reach the effective limit. It is necessary to reduce inventories by $55.95 \%$, foreign sources by $53.21 \%$, the number of employees by $35.61 \%$, receivables by up to $67.18 \%$ and the least desirable is to reduce total assets (Table $6)$. 
INSIGHTS INTO REGIONAL DEVELOPMENT

ISSN 2669-0195 (online) http://jssidoi.org/jesi/

2021 Volume 3 Number 2 (June)

http://doi.org/10.9770/IRD.2021.3.2(6)

Table 6. Reduction of items in ineffective units (\%)

\begin{tabular}{|lccccc|}
\hline & Total Assets & Resources & Receivables & Liabilities & Employees \\
\hline TN14 & 26,31 & 55,12 & 15,12 & 45,56 & $\mathbf{2 9 , 3 5}$ \\
\hline NI18 & 18,23 & 61,23 & 14,23 & 56,23 & $\mathbf{3 3 , 2 5}$ \\
\hline BB26 & & & 61,21 & $\mathbf{3 8 , 2 9}$ \\
\hline KE36 & 31,42 & 49,24 & 18,31 & 49,85 & $\mathbf{4 1 , 5 6}$ \\
\hline \hline Average & 17,21 & 58,23 & & $\mathbf{5 3 , 2 1}$ \\
\hline
\end{tabular}

In this extensive analysis, we also used the ZSG-DEA model to verify the achieved results. The value of the purpose function 1, and thus reached 26 units out of the examined 40 units, which makes up $63 \%$ of the examined sample. 14 units are inefficient. Most of them can be found in the Trenčín and Prešov regions.

\section{Conclusions}

The research focuses on the evaluation of the impact of determinants on the effectiveness of individual entities. In this case, the dependent variable is the input CCR and BCC efficiencies adjusted by the double bootstrap method. Subsequently, we used the truncated regression based on their recommendations. The predictive power of the model is higher in the case of the BCC model based on the Log likelihodd and R-squared indicators, while this model describes $74.43 \%$ of the variability of the basic set. The CCR model describes $71.57 \%$ of the variability of the base set. For this reason, we have given the exact values of the change of individual inputs for inefficient DMUs in the BCC models. For the purposes of this analysis, we have provided specific rules for practice. Exact implementation of methodology DEA for individual regions of the Slovak Republic with input models CCR and BCC, ZSG-DEA models, units such as TN14, NI18, BB26 and KE36 are identified as ineffective in three models to determine efficiency. In this model, we determined the necessary change in the level of inventories, the number of employees and total assets. BCC-input model - draw attention to monitoring the level of receivables, inventories and liabilities. The most effective units were identified by the ZSG-DEA model, where we identified, from a regular aspect, a region where it is necessary to change the approach to the development of this segment. In the case of reducing total assets, it is appropriate to focus on reducing the amount of surplus tangible movable and immovable property such as land, buildings, machinery or cars. Another possibility is the rationalization of already used premises and their further lease to external entities. Smaller but regular deliveries are preferred to achieve the optimum level of stocks, and at the same time the maximum freshness of the raw materials used. When reducing the number of employees or the number of jobs, it is necessary to follow the defined legislative rules. Possible solutions include changing the duties of the current and new employees.

Income from tourism is an important contribution to GDP, foreign exchange incomes, as well as provides job opportunities and has the potential to play a significant role in the revitalization of the economically weaker regions. Tourism might become an accelerator of the regional development and according to Horvath, Mikus, (2016) is associated with the assumption of balancing regional disparities. Direct income is generated via consumption of visitors in the tourist destinations, as well as indirect revenue is generated by taxes (Rajić, 
INSIGHTS INTO REGIONAL DEVELOPMENT

ISSN 2669-0195 (online) http://jssidoi.org/jesi/

2021 Volume 3 Number 2 (June)

http://doi.org/10.9770/IRD.2021.3.2(6)

Milošević, 2016; Zsigmond et al., 2020), levies and various fees introduced in individual regions. Entrepreneurship in tourism helps to develop all regions of Slovakia in long term. In our work we wanted to identify the individual factors that affect the efficiency of the examined accommodation facilities in terms of all regions of Slovakia.

\section{References}

Aisyah, S.; Imran, C; Ramli, A. 2017. Effect of characteristics and entrepreneurial orientation towards entrepreneurship competence and crafts and arts small and medium enterprises business performance in Makassar. International Review of Management and Marketing, 7 (2), 166-173.

Ballini, B., Rousseau Calisti, I.. 2019. Pan-European RRA Study on Family-Owned Business Family-owned companies' challenges and common peculiarities. 2020. [Online, 29.01.2020]. Available at: https://www.russellreynolds.com/insights/thought-leadership/2019-paneuropean-rrastudy-on-family-owned-business

Bačík, R., Fedorko, R., Rigelský, M., Warmasyah Abbas, E., Ivanková, V., Obšatníková, K.. 2019. The Impact of Selected Quality Management Attributes on the Profitability of TOP Hotels in the Visegrad Group Countries. Polish Journal of Management Studies 19 (1), 46-58.

Baša, P.; Sánta, K.; Machová, R. 2019. The Economic Impacts of Social Media's Implementation. RELIK 2019 12th International scientific conference : reproduction of human capital - mutual links and connections, pp. 33-42.

Belas, J.; Cepel, M.; Kotaskova, A.; Dvorsky, J. 2020. The Impact of Important Economic Factors on the Quality of Business Environment in the SME Sector. Proceedings of the 13th European conference on innovation and entrepreneurship (ECIE 2018), 94-101.

Binh, N.T. 2010. Analysis of Business Activities. Statistical publisher. Ha Noi.

Borocki, J.; Radisic, M.; Sroka, W.; Greblikaite, J.; Androniceanu, A. 2019. Methodology for Strategic Posture Determination of SMEs. Inzinerine ekonomika-Engineering economics, 30 (3), 265-277. https://doi.org/10.5755/j01.ee.30.3.21966

Cepel, M.; Stasiukynas, A.; Kotaskova, A.; Dvorsky, J. 2018. Business environment quality index in the SME segment. Journal of Competitiveness, 10 (2), 21-40. https://doi.org/10.7441/joc.2018.02.02

Cibik, L. 2018. Cohesion Policy from the Perspective of Territorial Self-Government in Slovakia in 2011-2016. Proceedings of the 4th international conference on european integration 2018 (icei 2018), pts 1-3. 4th International Conference on European Integration 2018 (ICEI 2018), 184-189

Cooper, W. W.; Seiford, L. M.; Tone, K. 2007. Data Envelopment Analysis: A Comprehensive Text with Models, Applications, References and DEA-Solver Software (2nd ed.). Springer US. Available at: www.springer.com/la/book/9780387452814

Csabay, M., Stehlikova, B. 2020. Firm Size Distribution and the Effects of Ownership Type. Journal of Competitiveness, 12(4), 22-38.

Curado, C.; Muñoz-Pascual, L.; Galende, J. 2018. Antecedents to innovation performance in SMEs: A mixed methods approach. Journal of Business Research, 89(August), 206-215.

Dagnino, C.; Cáceres Pinna, E. 2017. The Generational Change in Family Businesses: Comparative Analysis between Italy and Peru. Journal of Evolutionary Studies in Businesses, 2 (2), 160- 190

Duygulu, E.; Ozeren, E.; Pinar I.; Sildar, Appolloni, A. 2016. The Sustainable Strategy for Small and Medium Sized Enterprises: The Relationship between Mission Statements and Performance. Sustainability, 8(7), 698; https://doi.org/10.3390/su8070698

European Commission. 2016. Funds absorption rate. Retrieved from https://cohesiondata.ec. www.europa.eu/dataset/2007-2013-FundsAbsoption-Rate/kk86-ceun

European Commission. 2017. Value added at factor costs (\% of total value added by enterprises). Retrieved from https://ec.europa.eu/growth/smes/business-friendly-environment/performance-review-2016_ro 
INSIGHTS INTO REGIONAL DEVELOPMENT

ISSN 2669-0195 (online) http://jssidoi.org/jesi/

2021 Volume 3 Number 2 (June)

http://doi.org/10.9770/IRD.2021.3.2(6)

Farrell, M. J. 1957. The Measurement of Productive Efficiency. Journal of the Royal Statistical Society. Series A (General), 120 (3), $253-$ 290. https://doi.org/10.2307/2343100

Fernandes, F. D. S.; Stasinakis, C.; Bardarova, V. 2018. Two-stage DEA-Truncated Regression: Application in banking efficiency and financial development. Expert Systems with Applications: An International Journal, 96, $284-301$. https://doi.org/10.1016/j.eswa.2017.12.010

Herman, H..; Hady, H..; Arafah, W. 2018. The influence of market orientation and product innovation on the competitive advantage and its implication toward Small and Medium Enterprises (UKM) performance. International Journal of Science and Engineering Invention, 4(8). https://doi.org/10.23958/ijsei/vol04-i08/02

Horvath, P., Mikus, D. 2016. The political aspects of transformations into regionalization of Slovakia. SGEM 2016, BK 2: Political sciences, law, finance, economics and tourism conference proceedings, Vol I. 3rd International Multidisciplinary Scientific Conference on Social Sciences and Arts, SGEM 2016, 657-663

Charnes, A.; Clark, C. T.; Cooper, W. W.; Golany, B. A 1984. Developmental study of data envelopment analysis in measuring the efficiency of maintenance units in the U.S. air forces. Annals of Operations Research, 2, 95-112. https://doi.org10.1007/BF01874734

Chatzoglou, P.; Chatzoudes, D.; SarigiannidiS, L.; Theriou, G. 2018. The role of firm-specific factors in the strategy-performance relationship: Revisiting the resource-based view of the firm and the VRIO framework. Management Research Review, Emerald Group Publishing, 41 (1), 46-73.

Chong, P.; Ong, T.; Abdullah, A.; Choo, W. 2019. Internationalisation and innovation on balanced scorecard (BSC) among Malaysian small and medium enterprises (SMEs). Management Science Letters, 9(10), 1617-1632. https://doi.org/10.5267/j.msl.2019.5.025

Imrovic, M., Kovacik, V. 2019. Active Labour Market Policy in the Context of the Implementation of Operational Program Employment and Social Inclusion. Proceedings of the 13th international scientific conference public economics and administration 2019. 13th International Scientific Conference on Public Economics and Administration, 172-187

Kokocinska, M.; Puziak, M. 2018. Regional Income Differences and their Evolution after EU Accession. The Evidence from Visegrad Countries. Journal of Competitiveness, 10(4), 85-101. https://doi.org/10.7441/joc.2018.04.06

Kozubikova, L.; Kotaskova, A. 2019. The impact of technological factors on the quality of the business environment. Transformations in Business \& Economics, 18 (1), 95-108

Krizanova, A.; Gajanova, L.; Nadanyiova, M. 2018. Design of a CRM level and performance measurement model. Sustainability 10 (7), 2567

Mardani, A.; Zavadskas, E. K.; Streimikiene, D.; Jusoh, A.; Khoshnoudi, M. 2017. A comprehensive review of data envelopment analysis (DEA) approach in energy efficiency. Renewable and Sustainable Energy Reviews, 70, 1298-1322. https://doi.org/doi:10.1016/j.rser.2016.12.030

Matijová, M.; Onuferová, E.; Rigelský, M. 2019. Relations between performance tourism potential and economic outputs of the regions in the Slovak Republic. Acta Oeconomica Universitatis Selye 8(2), 28-40

McDonald, J. 2009. Using least squares and tobit in second stage DEA efficiency analyses. European Journal of Operational Research, 197(2), 792-798. https://doi.org/10.1016/j.ejor.2008.07.039

Khan, M.A.; Popp, J.; Talib, M.N.A.; Lakner, Z.; Khan, M.A.; Oláh, J. 2020. Asymmetric Impact of Institutional Quality on Tourism Inflows Among Selected Asian Pacific Countries. Sustainability, 12(3), 1223; https://doi.org/10.3390/su12031223

Lazikova, J.; Bandlerova, A.; Rohacikova, O.; Schwarcz, P.; Rumanovska, L. 2018. Regional Disparities of Small and Medium Enterprises in Slovakia. Acta Polytechnica Hungarica, 15 (8), 227-246. https://doi.org/10.12700/APH.15.8.2018.8.12

Machyniak, J. 2018. Public Policy Making Process - Theoretical Basic. Development, democracy and society in the contemporary world.5th ACADEMOS International Political Science Conference on Development, Democracy and Society in the Contemporary World, $221-225$ 
INSIGHTS INTO REGIONAL DEVELOPMENT

ISSN 2669-0195 (online) http://jssidoi.org/jesi/

2021 Volume 3 Number 2 (June)

http://doi.org/10.9770/IRD.2021.3.2(6)

Maris, M. 2015. Evolution of Regional Disparities in Spatial Dimension Urban versus Rural in V4 Countries. CERS 2014: 5th Central European Conference in Regional Science. International conference proceedings, 550-559

Melichová, K.; Hrivnák, M.; Roháčiková, O. 2017. Multiplier effects and economic impact of university spending - case study of sectoral and spatial aspects of expenditures of Slovak University of Agriculture in Nitra. Acta Oeconomica Universitatis Selye, 6(2), 119-137.

Morrison, E. W. 2011. Employee voice behavior: Integration and directions for future research. Academy of Management Annals, 5(1), 373-412.

Obeidat, S. M.; Mitchell, R.; Bray, M. 2016. The link between high performance work practices and organizational performance: Empirically validating the conceptualization of HPWP according to the AMO model. Employee Relations, 38(4), 578-595. https://doi.org/10.1108/ER-08-2015-0163

Podhorska, I., Siekelova, A., Olah, J. 2019. Earnings analysis of SMEs: A case study in Slovakia. Proceedings of the 33rd International Business Information Management Association Conference, IBIMA 2019: Education Excellence and Innovation Management through Vision 2020, pp. 8706-8718

Ramanathan, R.; Ramanathan, U. 2011. A performance measurement framework combining DEA and balanced scorecard for the UK health sector. International Journal of Operational Research, 12(3), 257-278. https://doi.org/10.1504/IJOR.2011.042916

Rajić, T., Milošević, I. 2016. An empirical analysis of the determinants of SME's customer loyalty: evidence from Serbia. Acta Oeconomica Universitatis Selye 5(1), $79-89$

Ślusarczyk, B., Ul Haque, A. 2019. Public services for business environment: challenges for implementing Industry 4.0 in Polish and Canadian logistic enterprises. Administratie si Management Public, (33), pp. 57-76,

Smerek, L.; Vetráková, M. 2020. Difference in human resources development in various types of companies. Polish Journal of Management Studies, 21(2), pp. 398-411

Stacho, Z., Stachová, K., Cagáňová, D., Blštáková, J. 2021. The Key Managerial Competencies Tendencies Application in the Business Environment in Slovakia within the Context of Industry. EAI Endorsed Transactions on Energy Web, 8(32), pp. 1-9

Udriyah, U.; Tham, J.; Azam, S. 2019. The effects of market orientation and innovation on compet-itive advantage and business performance of textile SMEs. Management Science Letters, 9(9), 1419-1428. https://doi.org/10.5267/j.msl.2019.5.009

Shi, G.-M.; Bi, J.; Wang, J.-N. 2010. Chinese regional industrial energy efficiency evaluation based on a DEA model of fixing non-energy inputs. Energy Policy, 38(10), 6172-6179. https://doi.org/10.1016/j.enpol.2010.06.003

Shih, T. Y. 2018. Determinants of enterprises radical innovation and performance: Insights into strategic orientation of cultural and creative enterprises. Sustainability, 10(6), 1871. https://doi.org/10.3390/su10061871

Štefko, R., Bačík, R., Fedorko, R., Horváth, J., Propper, M., Gavurová, B. 2017. Gender differences in the case of work satisfaction and motivation. Polish Journal of Management Studies. 16(1), 215-225.

Tamulevičienè, D.; Androniceanu, A. 2020. Selection of the indicators to measure an enterprise's value and its changes in the controlling system for medium-sized enterprises. Entrepreneurship and Sustainability Issues 7(3): 1440-1458. https://doi.org/10.9770/jesi.2020.7.3(1)

Teles, D.; Schachtebeck, C. 2019. Entrepreneurial Orientation in South African Social Enterprises. Entrepreneurial Business and Economics Review, 7(3), 83-97. https://doi.org/10.15678/EBER.2019.07030

Tien, N.N.; Manh, D.D. 2018. Current situation of profitability of assets and equity in small and medium enterprises in Binh Dinh province. Journal of Economics and Forecasting, 33(11), 49-52. https://doi.org/10.5267/j.msl.2019.7.007

Thames, L.; Schaefer, D. 2016. Software-Defined Cloud Manufacturing for Industry 4.0. Procedia CIRP, 52: $12-17$. https://doi.org/10.1016/j.procir.2016.07.041

Vekic, A., Djakovic, V., Borocki, J., Sroka, W., Popp, J., Olàh, J. 2020. The importance of academic new ventures for sustainable regional development. Amfiteatru Economic, 22(54), pp. 533-550 
INSIGHTS INTO REGIONAL DEVELOPMENT

ISSN 2669-0195 (online) http://jssidoi.org/jesi/

2021 Volume 3 Number 2 (June)

http://doi.org/10.9770/IRD.2021.3.2(6)

Virglerova, Z., Kliestik, T., Rowland, Z., Rozsa, Z. 2020. Barriers to internationalisation of SMEs in Visegrad group countries. Transformations in Business and Economics, 19(3), pp. 58-73

Zahra, Ian. An Analysis into the Definition of a „Family Business“ in the Family Business Act, A term paper submitted in partial fulfilment of the requirements for the Degree of Bachelor of Laws (Honours), Faculty of Laws, University of Malta. 2017. [cit. 9. 6. 2020] Available at: https://economy.gov.mt/en/familybusinessact/Family\%20Business/Documents/Family\%20Business\%20Term\%20Paper.pdf

Zsigmond, T.; Korcsmáros, E.; Machová, R.; Šeben, Z. 2020. Interconnection of Consumer Behaviour of Different Generations and Marketing Strategy of a Football Club - Experience in Slovakia. Marketing and Management of Innovations, 2, 221-234. http://doi.org/10.21272/mmi.2020.2-16

Waal, A. 2013. Strategic Performance Management. Hampshire: Palgrave Macmillan. ISBN 978-0-230-27385-6.

Wach, K. 2020. A Typology of Small Business Growth Modelling: A Critical Literature Review. Entrepreneurial Business and Economics Review, 8 (1), 159-184. http://doi.org/10.15678/EBER.2020.080109

\section{Acknowledgements}

Scientific Paper was elaborated and financed within the framework of the project VEGA 1/0813/19 Managing the development of innovative and start-up forms of businesses in international environment and verification of INMARK concept and GAAA 5-5/2020 Development of family business in Slovak regions. This research was funded by VEGA 1/0240/20 Financial aspects of business sustainability - business succession in small and medium enterprises, too.

Ladislav Mura is an Associate Professor, a Slovak expert on small and medium business, international business, and human resource management. He is the author of 3 domestic scientific monographs on the internationalization of business, small and medium enterprises, human resource management, co-author of foreign scientific monographs. He has published a lot of articles in various scientific journals.

ORCID: https://orcid.org/0000-0002-2453-8740

Zuzana Hajduová is an expert on statistical methods, mass data processing, combinatorial structures and systems theory, as well as their application in economic practice. She concentrates her empirical research on quality, focusing on Six Sigma. She has a rich and thematically extensive publishing activity. She is a member of many scientific committees of international and national conferences. She participated in several domestic and international projects (Interreg IV.C, V4, Horizont 2020). ORCID: https://orcid.org/0000-0002-9381-776X

Make your research more visible, join the Twitter account of INSIGHTS INTO REGIONAL DEVELOPMENT: @IntoInsights

Copyright (C) 2021 by author(s) and VsI Entrepreneurship and Sustainability Center This work is licensed under the Creative Commons Attribution International License (CC BY). http://creativecommons.org/licenses/by/4.0/ 